\title{
Ferreira, Marieta de Moraes A História como ofício: a constituição de um campo disciplinar
}

(History as an art: the creation of a disciplinary field)

Lidiane S. Rodrigues*

Rio de Janeiro: Ed. FGV, 2013. 464p.

Marieta de Moraes Ferreira's book, recently launched by Fundação Getulio Vargas' publishing house, is at the spearhead of current research in the history of historiography. I do not say this as a favor, nor as a protocol of the review genre.

Any shrewd observer of the area would note the growth of research prioritizing 'great men' or 'great works,' especially in relation to the more recent times and to Brazil. Since the studies of Manoel Salgado Guimarães, the nineteenth century has gained analyses focusing on the nexus between institutions, their sociability, and the concepts of history in them and arising out of them (Guimarães, 2011). Twentieth century authors are reserved a type of rapture, as if they were 'floating intellectuals' - especially in regard to essayists before the turn that gave rise to university institutions which from the 1930s onwards would concentrate teaching and gradually research in history. ${ }^{1}$

We slowly have gone beyond this phase, and A História como ofício: a constituição de um campo disciplinar appears to both collaborate in this direction and be a sign of it. The book is divided into three parts, namely: "The History of History in Rio de Janeiro: from UDF to UFRJ"; "Profiles and trajectories"; and "Interviews with students and professors from UDF, FNFI and IFCS".

The first part contains a detailed reconstitution of the vicissitudes involved in the establishment of the first course in history in Rio de Janeiro, using a diversified set of sources and a considerable amount of information: the social and intellectual profile of professors, the curriculum, programs from the course, federal decrees, and programmatic texts.

^Centro Universitário Fecap (Fundação Escola de Comércio Álvares Penteado). lidiane.rodrigues@ fecap.br 
In the second part the scale changes, moving to a wide frame of reference than in the first, with a focus concentrated on the trajectories of Henri Hauser, Delgado de Carvalho and Luiz Camillo, as well as the first actually 'professional' generation in Rio de Janeiro. It is worth pointing out the author's meticulous attention to the figure of Hauser, linked to her concern with sifting through the paths of institutional memory which were overvalued in the presence of the French mission in São Paulo, to the detriment of their presence in the capital (p.86 and 217). Two quick observations about this are relevant: Marieta de Moraes Ferreira went to the archives of the Ministry of Foreign Affairs (MAE) in Nantes to investigate the networks involved in the recruitment of staff and the interest of France in teaching in Brazil. For those who are not satisfied with a history of historiography which hides the behind-thescenes areas through which all those who practice the craft passed before shining on stage or during a spectacle, this attitude is exciting and opens a wide range of options for new research.

This observation leads to the next. As a researcher of French missions in the courses of History and Geography of Universidade de São Paulo (USP) in its initial years, I found in the warning that analyzes have "overvalued the role of Fernand Braudel and the influence of the Annales as central elements in the formation of History courses" (p.92) the supporting perspective I had lacked for years. At another opportunity I could explain how the 'missionary historian' was kept under the reins of friendship and services rendered to his clientele - the mentoring elite of the former Faculty of Philosophy, Science, and Letters of USP, which in turn was constantly fighting with the federal government. The possibilities of not reproducing a 'historicizing history', against which his work had already been prepared, were limited. Anyone who links immediately the reception of the Annales to the presence of Braudel between 1935 and 1937, and even later in his brief passages in USP, will suffer from the lack of empirical support, (Rodrigues, 2012, p.256-276).

The third part, in which interviews are transcribed, seems to be of special interest, read in light of the composition of the book. In these it is possible to find alternative versions of the conflicts which animate the narrative of the author and to glimpse the exits constructed to simultaneously consider what she heard when placing tête-à-tête, oral versions and written documentation.

Finally, a particular trait of the book should be emphasized. It is presented without great theoretical or methodological pretentions, going against the tendency to present long introductions and citations of momentous authors, whose link with the research sometimes leaves a lot to be desired. Dealing all 
the time with notions of institutionalization and the autonomization of scientific practices, related to Pierre Bourdieu's limits of the concept of the field, these are reconstituted in terms of their process of creation. Stated in another manner, highlighting both advances and setbacks in the trajectory of the separation between political and ecclesiastic powers and institutions of knowledge - thus, more than the obvious attention aimed at interventions of the federal government in the establishment/closing of institutions, attention to the profile of Catholic teaching staff and their teaching orientation (notably, pp. 3840). Concomitantly, they are the subject of processes of the internal division of labor in this space - not exactly autonomous, but in constant conflict for autonomy, at a certain point in the rotation of teacher and student profiles (notably the division into two separate courses, Geography and History, and the establishment of the discipline "Introduction to Historic Studies").

A book you learn from, a book to devour.

\section{REFERENCES}

GUIMARÃES, Maria Lucia Paschoal. Debaixo da imediata proteção imperial: Instituto Geográfico Brasileiro (1838-1889). [1995]. São Paulo: Annablume, 2011.

MICELI, Sergio. Intelectuais à brasileira. São Paulo: Companhia das Letras, 2001.

RODRIGUES, Lidiane S. A produção social do marxismo universitário em São Paulo (1958-1978). Doctoral Dissertation - FFLCH, Universidade de São Paulo. São Paulo, 2012.

\section{NOTE}

${ }^{1}$ Perhaps for this reason the analytical scheme offered by Miceli (2001), which is still far from being incorporated, for understanding "intellectuals/historians unattached to institutions" still causes some furor.

Review received on 25 June 2013. Approved on 15 October 2013. 